\title{
Student Presence Using RFID and Telegram Messenger Application: A Study in SMK Unggulan Terpadu Pgii Bandung, Indonesia
}

\author{
Muhammad Benny Chaniago ${ }^{1} \&$ Apri Junaidi ${ }^{2}$ \\ ${ }^{1}$ Information System Department, Faculty of Engineering, Widyatama University, 204 A Cikutra Street, Bandung, \\ Indonesia \\ ${ }^{2}$ Informatics Engineering Department, Faculty of Engineering, Widyatama University, 204 A Cikutra Street, Bandung, \\ Indonesia \\ Correspondence: Muhammad Benny Chaniago, Information System Department, Faculty of Engineering, Widyatama \\ University, 204 A Cikutra Street, Bandung, Indonesia. E-mail: benny.chaniago@ widyatama.ac.id
}

Received: April 4, 2018

Accepted: September 28, 2018

Online Published: May 15, 2019

doi:10.5430/ijhe.v8n3p94

URL: https://doi.org/10.5430/ijhe.v8n3p94

\begin{abstract}
Students in Indonesia have been cutting classes for some time now and it has become a bad habit. They leave their house toward their educational institutions, either school or college, but in fact, they go somewhere else. The issue was supported by the lack of communication between the schools and parents related to the student attendance. Dealing with the problems mentioned above, it is required to create a Telegram Messenger application for student presence as a solution. Application-based student presence Telegram Messenger was made to ensure that students attend classes, by steps as follow: firstly, students must hand in the ID card to the teacher on duty, then the teacher will tap the card, and finally the data will be recorded and be saved in the database automatically. The data will be saved automatically every day, and then it will be sent personally to their parents who had their mobile phones registered to receive information regarding their children presence at school on the particular date and hour. In addition, this application provides service for the parents to find the information on daily and monthly basis. This application can also be a part of consideration in decision making for the principals by downloading student attendance data in Microsoft Excel file format. The implementation of the applications based on Telegram Messenger for students' presence at school was expected to be a solution for the problems of student absence due to skipping school. This application has been tested in SMK Unggulan Terpadu PGII Bandung with very satisfying results and the level of student absence was able to be fixed.
\end{abstract}

Keywords: presence, ID card, RFID, telegram messenger

\section{Introduction}

Nowaday, with the development of Information Technology, humans tend to require precise, accurate and reliable information without any limits of distance and time. With the growing development of technology, the needs for a tool to solve the problems are increasing. It can be either an electronic device known as the computer that serves as a data processor which will process the data so that it becomes essential information for humans. In processing the data into information, it can be explained that the computer has a very important role in generating data quickly and accurately.

Data attendance (presence) is one of the most important information at a company, institution or organization, especially the attendance report that will form the guidelines for the management in making decisions. Presences in the conventional recording methods often complicate the administrative department. Conventional presence by the form of a signature on a paper becomes less quick and efficient.

Using Telegram Messenger at school is expected to provide data on student attendance accurately through a system that can be monitored such as student attendance, the data of circular activity from the beginning to the end of the studying process. After that, the information obtained from the processing of Telegram Messenger is processed into a report for parents. Data that has been saved into computer will be then processed into weekly and monthly reports for the principle, management and parents.

Generally, the discussion in this paper is arranged over several sessions: Introduction, describes a general overview of the research that is being made. Literature Review explains the references used to compile the study. The Related Works overviews several studies in the same fields. Propose Method describes the proposed system to be developed in 
this study. Implementation contains implementing the method used in the application form. The last part is Conclusions that contains the conclusion obtained during research conducted.

\section{Methodology}

Methodology is a science or methods used to obtain the truth using search to any particular procedure in finding the truth depending on the reality that is being studied.

As a scientific framework, methodology emphasizes the expertise of researchers in examining the relevance of a method, whether it is still in use or vice versa and then determines the other methods that are relevant to the research. Meanwhile, as a process, a methodology is relating to the operations and attributes. And of the overall workings, proceeded by a fundamental question, namely: "to what a study done?"

Based on several references, this study is designed for Students Presence Using RFID and Telegram Messenger in SMK Unggulan Terpadu PGII Bandung with the architecture as seen in Figure 1.

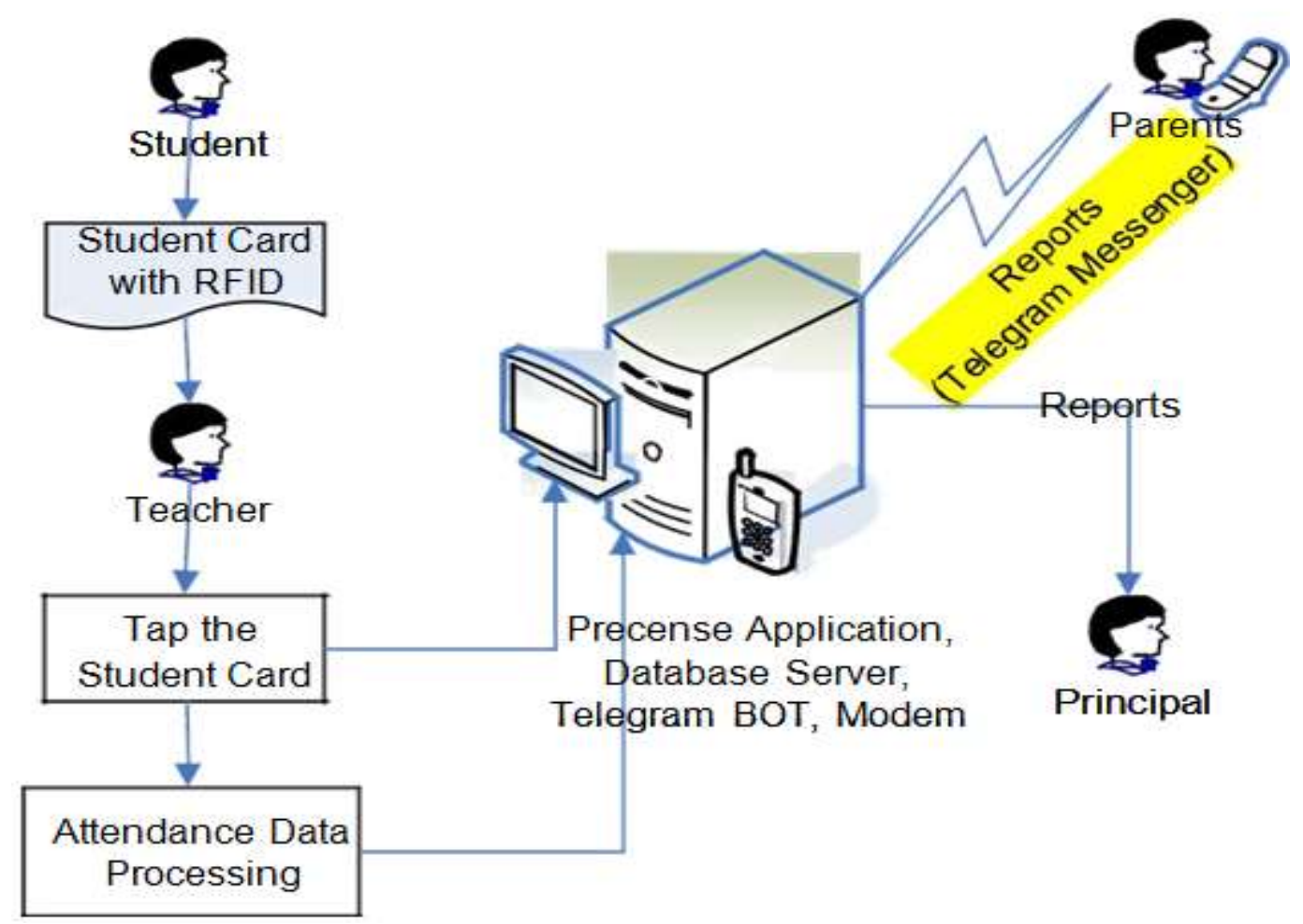

Figure 1. Architecture of Telegram Messenger for Student Presence.

Method which is used in Figure 1 shows that the students come straight to their teachers for tapping the student card. Then, the data which has been inputted will be stored in the database. As the data is stored in the database, the next process is the data processing on Telegram Messenger and then sends a notification in the form of Telegram Messenger to each parent that their children have arrived at school.

Student attendance data is also processed into a report to the principal regarding student attendance that can be downloaded in excel format.

\section{A. System Analysis}

The system used previously was neither yet computerized nor manual. Problems appeared with the data processing media which is not yet computerized. Therefore, the system is proposed to create a new system with the computer application program to facilitate the school regarding student attendance data and information, easily and accurately.

\section{B. Data Analysis}

Data analysis is the analysis activities categorizing data to find patterns of relationships, themes, interpret what is meaningful, and convey or report it to others who are interested.

The required data are student attendance data, parent data, student data and on duty teacher data. 


\section{Information Analysis}

For the purpose of decision making, it needs some forms of report, such as daily and monthly recapitulation attendance, and also daily and monthly recapitulation presence in the form of Telegram Messenger.

\section{Literature Review}

\section{Radio Frequency Identification (RFID)}

RFID is particularly classified as "better bar code" is advertised, and "smart barcode." The media announced regularly that the days of bar code are numbered and that RFID will replace barcodes immediately. Recently, the fact shows RFID has some clear advantages over the barcode, but bar codes provide several distinct advantages over RFID. Behind all of enthusiasm over the advantages of RFID to bar codes that are advertised by media; the other side is quietly, sometimes deliberately, neglected in the press. As a result, a common belief form that barcodes are a safe loser when compared to RFID, regardless of the context. This is a completely false belief Brannon. 1995; Firdaus, 2010.

Applications designed with RFID would be possible to be as an wireless integrated devices such as cellular phones, tablets, sensor so that the application can ubiquitously be accessed Lahiri, 2005; Nair \& Hui, 2018. The RFID technology is a wireless communication method that by mounting the IC chip RFID tags on objects, read the unique value recorded in the RFID tag, and to distinguish objects with RFID tags with the value called operates (Önder, 2018; Zheng,2018; Anwar, 2018). Radio Frequency Identification (RFID) is an identification technology that uses radio waves to transfer the identity information stored in RFID tags for RFID readers (Jabarullah \& Hussain, 2019).

\section{B. RFID Readers}

A traditional radio receiver requires many analog components, as is First in Figure 2, the radio signal is shown being received by the antenna and is then amplified by an LNA graced (low noise amplifier). These parts will be shared by all the radio channels (Okon \& Richard, 2017; Obi \& Okekeokosisi, 2018). After these components a receiver for each channel required. The RF signal is converted downwards by a mixer, to the baseband and a local oscillator. At each level are analogous filters used to distinguish the signal outside the frequency band. The last step prior to the digitization is to decompose the signal into in-phase and quadrature components. These signals are then converted into a narrow band analog-to-digital converter (ADC). In UHF, for example, FCC regulations limit the total band width to $25 \mathrm{MHz}$, while the channel bandwidth is about $500 \mathrm{kHz}$. A reader can therefore treat more than 50 channels (Jamali \& Cole. 2008).

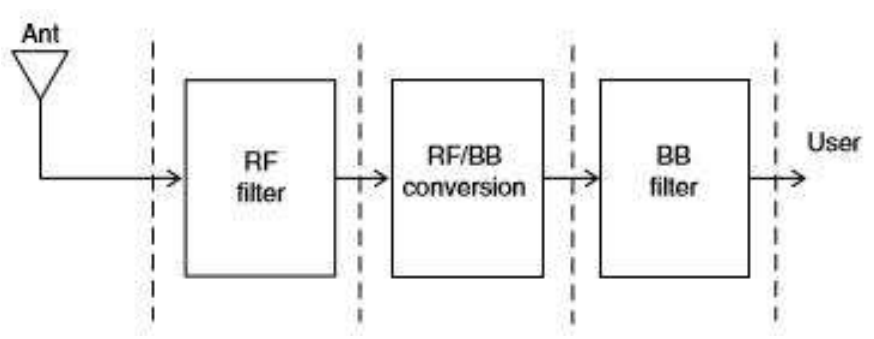

Figure 2. Simplified Hardware Chain of A Traditional RFID Reader.

RFID Reader is used as a medium for reading data transmitted through the RFID card and processed into a variety of data through radio signals (Jamali \& Cole. 2008).

\section{Telegram Messenger}

To get a messaging app that has good performance such as speed and security and can be used on mobile devices, now you can use the Application Telegram, the Telegram messages can be synchronize on all computer equipment, including mobile equipment (Kamoun, 2009; Kim, Park, \& Lee. 2009; Said, et.al.2014; Rusok, et.al. 2017; Riyanti, 2018; Saeed \& Kayani, 2018; Salim \& Hariandja, 2018; Sandy, 2018).

Telegram application capable of sending data into Messeger group of 5000 members and is able to handle all types of files that can be read by a mobile device or computer. like a regular telephone Telegram read and write a list of contacts and send messages in the form of SMS and email. 
Telegram is a cloud-based messenger applications and is easy to be synchronized so that you can access messages from a variety of devices such as tablets and computers with the amount of up to $1.5 \mathrm{~GB}$ per person for photo files, video and file sharing such as doc, zip, $\mathrm{mp} 3$ and others. And if you have limited storage device so your data will always be safely stored in the cloud.

A program used API for developers to create their own applications that are still based on the Telegram, the API allows people to create an application in accordance with the needs of software development, creating a new application with its own needs.

Telegram Messenger has 3 important files which are Telegram.apk, Directory storage files located in the local memory of the smartphone, and database of all the activities to be carried out in further testing and analysis, as shown in Figure 3 (Puteri, 2018).

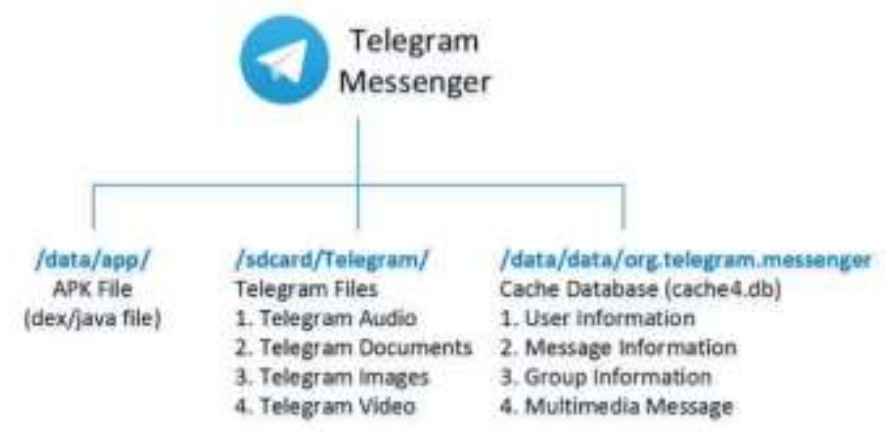

Figure 3. Structure Telegram Messenger

\section{Related Work}

Some of the equivalent researches in the field of SMS Gateway have been carried out by previous researchers such as: Ozkurt \& Alpay, 2018 how people can chat through SMS to other internet users. The system is called Smart Gateway which can connect SMS user with internet user to support chat conference service. This service is implemented especially for supporting online discussion in a teacher learning community. The very fundamental use of SMS technology research has been done by Zhu, et.al. 2012. Teacher will be able to encourage students to review previous subject materials and increase their understanding of these materials. Students who received reviews had a better understanding by being able to answer more questions than students who did not. Other researchers have developed a personal Short Messaging Service (SMS) server that is easy to manage by school IT administrator and easy to be developed into an SMS application system which is cost effective and is not bound to the SMS Gateway Service Provider (Subekti, et.al. 2013; Senussi, 2014; Satrya, et.al. 2016; Özmaden, Soter, \& Özmaden, 2018; Sudaryana, 2018; Tang \& Khan, 2018; Wang \& Yang, 2018). Other studies have also mentioned the development of an attendance system using fingerprint biometric technology that is equipped by Visual Basic Studio and Fingerprint Reader (Phoutthaphone, et.al. 2017).

\section{Implementation and Result}

\section{A Application Design}

Based on the analysis has been executed, some of the functional requirements of applications that will be built can be seen in use case in Figure 4. 


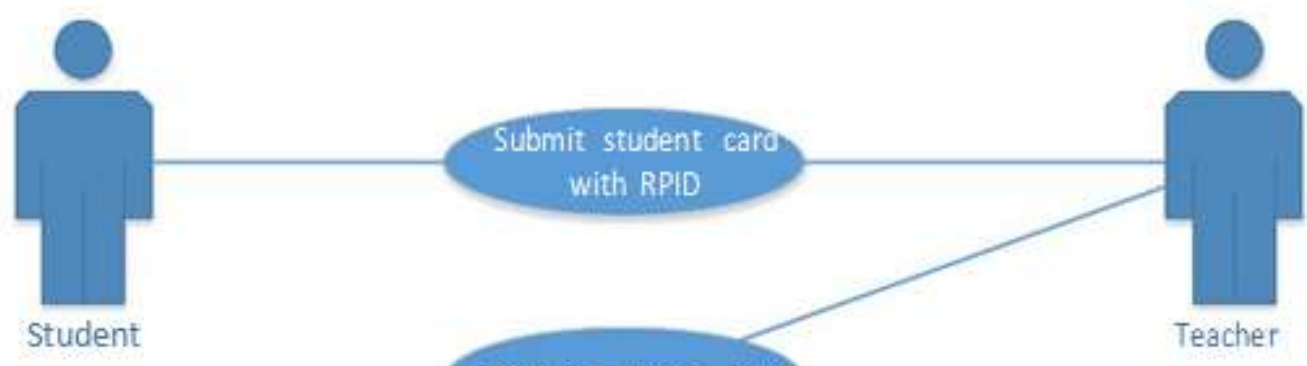

\section{Tapping student card}

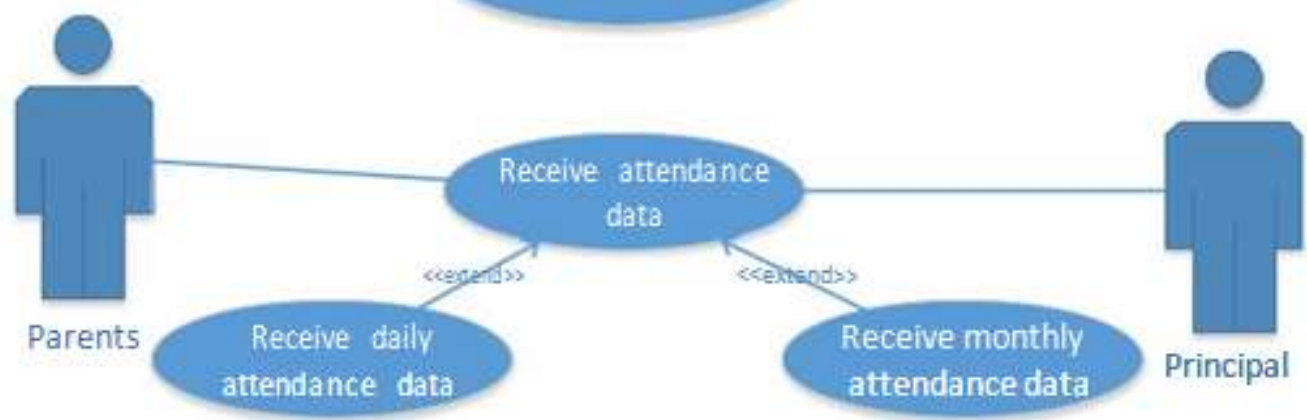

Figure 4. Use Case of Student Presence Using RFID and Telegram Messenger.

\section{B. Application Requirements}

The required hardware based on the minimum requirements must be met.

For server requirement, a minimum of an Intel Pentium 4 or similar, at least $1 \mathrm{~GB}$ of RAM, hard drive for media storage, at least $1 \mathrm{~GB}$ for the server, exclude the database, mouse, keyboard, and monitor as interface equipment are required.

For client: Using a minimum of an Intel Pentium 4 or similar, use a minimum of 512 MB RAM, mouse, keyboard, and monitor as an interface equipment, RFID reader and GSM modem or GSM phone are required.

To support the system that will be implemented, it requires both hardware and software, which are very useful for data processing. The following software specifications are needed, namely: Operating system, operating system used to run this application is Microsoft Windows XP, which has a fairly high reliability and performance in supporting the work of other software. Programming language is required to run the application. Programming language can process a variety of data so as to produce a desired output. In this case, the programming language used is PHP Script. Macromedia Dreamweaver 8 is used for the display design. The database used is MySQL.

Hardware and software will not work if it is not supported by the brain ware. Device specifications for brain ware are required to run and maintain the system that has been designed and specified as follows: Admin, admin has a responsible to operate the applications that have been applied, and they have tremendous access right to run the application, the admin has also the right to manage the databases that exist in the system. Users, minimum application users have the ability to operate a computer.

The user interface which is proposed in this study is used to carry out all the functions which are compatible for all application development needs and goals. 


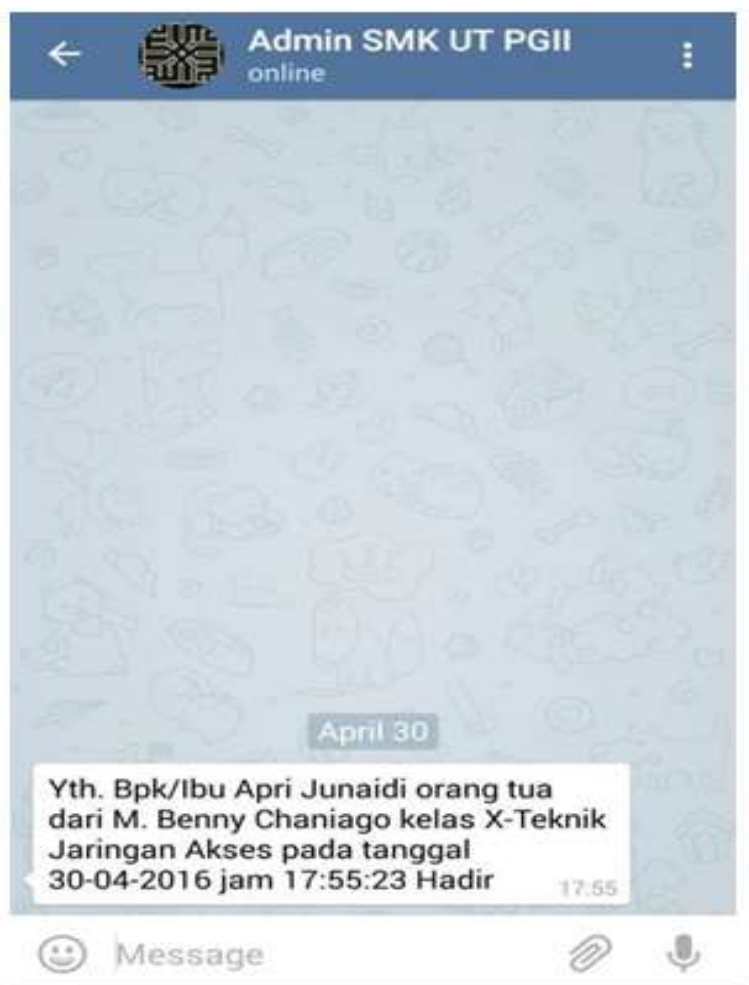

Figure 5. Telegram Messeger Report Format for Parents whose children attend the class.

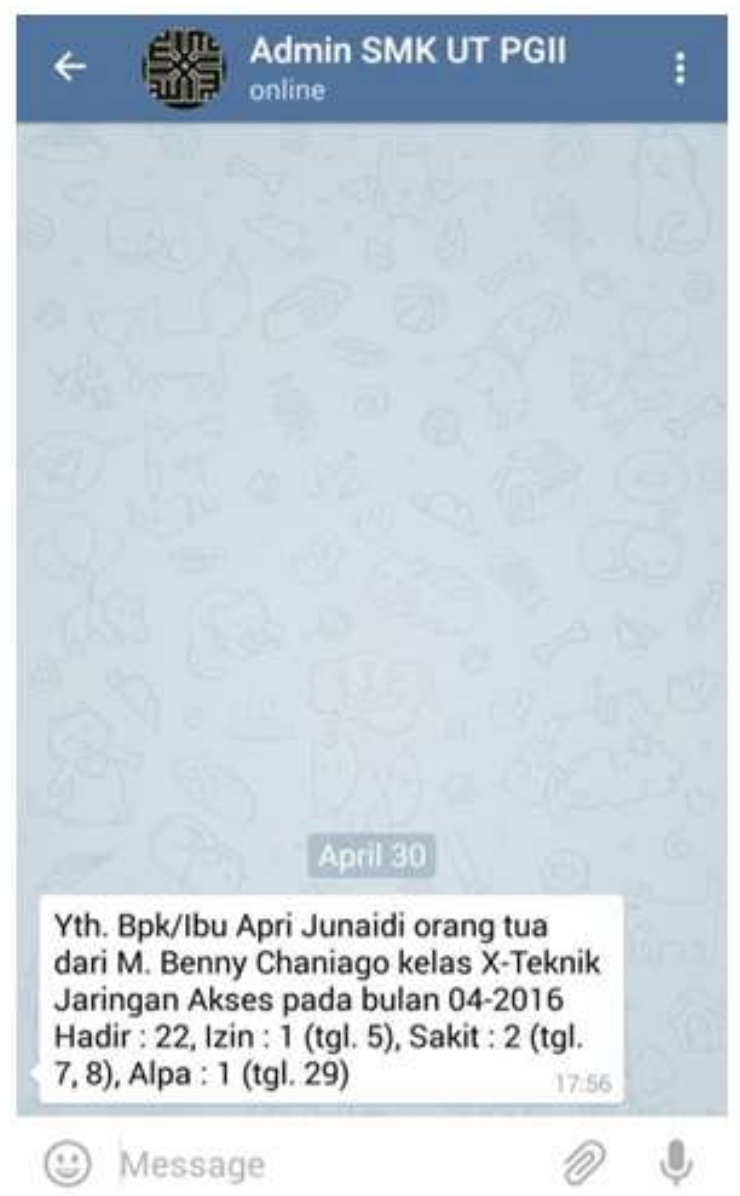

Figure 6. Telegam Messenger Report Format for Parents whose children are absent in class. 
Another user interface has already been designed for this study, such as administration form to create some reports and data recapitulation.

C. Result

Below is the data before and after the application is applied, the data taken in the four months before and four months after the use of data applications.

Table 1. Student Attendance List before Implementing the System

\begin{tabular}{|c|c|c|c|c|c|}
\hline \multirow{3}{*}{ Class } & \multicolumn{2}{|l|}{ Total of } & \multirow{3}{*}{ February } & \multirow{3}{*}{ March } & \multirow{3}{*}{ April } \\
\hline & & January & & & \\
\hline & \multicolumn{2}{|l|}{ Students } & & & \\
\hline X TJA & 40 & 35 & 34 & 36 & 37 \\
\hline X MM & 40 & 36 & 36 & 35 & 36 \\
\hline XI TJA & 40 & 34 & 36 & 37 & 37 \\
\hline XI MM & 40 & 36 & 34 & 35 & 36 \\
\hline XII TJA & 35 & 30 & 30 & 32 & 33 \\
\hline XII MM & 30 & 29 & 30 & 28 & 29 \\
\hline
\end{tabular}

Table 2. Student Attendance List after Implementing the System

\begin{tabular}{|c|c|c|c|c|c|}
\hline \multicolumn{6}{|c|}{ Total of } \\
\hline Class & & May & June & July & August \\
\hline \multicolumn{6}{|c|}{ Students } \\
\hline X TJA & 40 & 38 & 40 & 40 & 40 \\
\hline X MM & 40 & 38 & 40 & 40 & 40 \\
\hline XI TJA & 40 & 39 & 40 & 40 & 40 \\
\hline XI MM & 40 & 38 & 40 & 40 & 40 \\
\hline XII TJA & 35 & 34 & 35 & 35 & 35 \\
\hline XII MM & 30 & 30 & 30 & 30 & 30 \\
\hline
\end{tabular}

From the two tables above shows the improvement of student attendance prior to use Telegram Messenger system and RFID Technology for Presence. 


\section{Conclusions}

Conclusions that can be drawn by the presence of students with a system built using RFID and Telegram Messenger: the computerized attendance system of students in SMK Unggulan Terpadu PGII Bandung; allow schools to recap attendance data without using the manual method (Dawood, Muchallil, \& Munadi, 2013). With the construction of this system, parents can control their children by obtaining information in the form of text messages sent from the management about the presence of their children in school.

\section{References}

Anwar, M. N. (2018). Acquisition of Skills for Listening Comprehension: Barriers and Solutions. International Journal of English Language and Literature Studies, 7(3), 50-54.

Brannon. B. (1995). Basics of designing a digital radio receiver. Greensboro, North Carolina: Analog Devices Inc..

Dawood, R., S. Muchallil, \& K. Munadi. (2013). Meuruno : An SMS-based Learning System that Nudge Students to Review Previously Taught Materials. no. August, 321-324. https://doi.org/10.1109/TALE.2013.6654453

Firdaus. S. (2010). The Development of the Short Messaging Service (SMS) Application for the School Usage. 1382-1386.

Jabarullah, N.H. \& Hussain, H.I. (2019). The Effectiveness of Problem-Based Learning in Technical and Vocational Education in Malaysia. Education + Training. https://doi.org/10.1108/ET-06-2018-0129

Jamali. B. \& P. H. Cole. (2008). RFID handbook Aplications, Technology, Security and Privacy. Boca Raton: CRS Press.

Kamoun. F. (2009). RFID System Management: State-of-the Art and Open Research Issues, 6(3), 190-205. https://doi.org/10.1109/TNSM.2009.03.090305

Kim, S., H. Park, J. Lee, \& S. Lee. 2009 International Conference on New Trends in Information and Service Science A Study on Control Method to Reduce Collisions and Interferences between Multiple RFID readers and RFID tag. no. February 2005, 2009. https://doi.org/10.1109/NISS.2009.231

Lahiri. S. (2005). RFID Sourcebook. Massachusetts: Prentice Hall PTR.

Nair, S. M., \& Hui, L. L. (2018). An Analysis of Common Errors in ESL Descriptive Writing among Chinese Private School Students in Malaysia. International Journal of Education and Practice, 6(1), 28-42. https://doi.org/10.18488/journal.61.2017.61.28.42

Obi, M. N., \& Okekeokosisi, J. (2018). Extent of Implementation of National Entrepreneurship Curriculum in Tertiary Institutions as Perceived by Educators. American Journal of Education and Learning, 3(2), 108-115. https://doi.org/10.20448/804.3.2.108.115

Okon, E. O., \& Richard, S. H. (2017). Gender and Transport Sector Employment: Evidence from Kogi State, Nigeria. American Journal of Education and Learning, 2(1), 1-13. https://doi.org/10.20448/804.2.1.1.13

Önder, M. (2018). Contribution of Plays and Toys to Children's Value Education. Asian Journal of Education and Training, 4(2), 146-149. https://doi.org/10.20448/journal.522.2018.42.146.149

Ozkurt, B., \& Alpay, C. B. (2018). Investigation of Proactive Personality Characteristics of the Students of High School of Physical Education and Sports through Various Variables. Asian Journal of Education and Training, 4(2), 150-155. https://doi.org/10.20448/journal.522.2018.42.150.155

Özmaden, M., Soter, F., \& Özmaden, H. (2018). The Physical Education and Sport Studies in the Framework of Social Demands-Institutional Structuring and Teacher Training the Developments before and during Turkey Training Community Alliance Period (1922-1936). Asian Journal of Education and Training, 4(3), 170-175. https://doi.org/10.20448/journal.522.2018.43.170.175

Park, J. and J. Chung. Mobile RFID Reader-Initiated LLRP Connection Management, 1205-1209.

Phoutthaphone, S., Dahuai, Y., \& Jing, W. (2017). Application of Marxist Philosophy in Higher Educational Institutions in Lao PDR. International Journal of Asian Social Science, 7(8), 674-683. https://doi.org/10.18488/journal.1.2017.78.674.683

Puteri, L. H. (2018). The Apperception Approach for Stimulating Student Learning Motivation. International Journal of Education, Training and Learning, 2(1), 7-12. https://doi.org/10.33094/6.2017.2018.21.7.12 
Riyanti, M. T. (2018). Development of Learning Devices Commercial Graphic Based Planning Project. International Journal of Education, Training and Learning, 2(1), 1-6. https://doi.org/10.33094/6.2017.2018.21.1.6

Rusok, N. H. M., Kumar, N., \& Ab Rahman, S. M. (2017). A Contemporary Approach to Entrepreneurship Education and Training. International Journal of Asian Social Science, 7(8), 696-707. https://doi.org/10.18488/journal.1.2017.78.696.707

Saeed, N., \& Kayani, A. I. (2018). Role of College Principals in Promoting Quality of Education in District Kotli AJ\&K. Asian Journal of Contemporary Education, 2(2), 149-158. https://doi.org/10.18488/journal.137.2018.22.149.158

Said, M. A. M., M. H. Misran, M. A. Othman, M. M. Ismail, H. A. Sulaiman, A. Salleh, \& N. Yusop. (2014). BIOMETRIC ATTENDANCE, no. Istmet, 258-263.

Salim, M. N., \& Hariandja, N. M. (2018). Factors affecting joint stock price index (CSPI) and the impact of foreign capital investment (PMA) Period 2009 to 2016. Humanities and Social Sciences Letters, 6(3), 93-105. https://doi.org/10.18488/journal.73.2018.63.93.105

Sandy, W. (2018). Factors Influencing Indonesian Students Satisfaction During their Studies in China. Asian Journal of Contemporary Education, 2(2), 136-148. https://doi.org/10.18488/journal.137.2018.22.136.148

Satrya, G. B., P. T. Daely, \& M. A. Nugroho. (2016). Digital Forensic Analysis of Telegram Messenger on Android Devices. https://doi.org/10.1109/ICTS.2016.7910263

Senussi, G. H. (2014). Combind Effect of Machining Parameters With Nose Radius of the Custting Tool on Surface Roughness of 304-Austenitic Stainless Steel Alloy Produced by Cnc-Turning Machin. Review of Industrial Engineering Letters, 1(2), 44-54. https://doi.org/10.18488/journal.71/2014.1.2/71.2.44.54

Subekti, L. B. Y. Bandung, \& E. Cahyadi. (2013). Smart Gateway System for Supporting Online Discussion in Teacher Learning Community. https://doi.org/10.1109/rICT-ICeVT.2013.6741491

Sudaryana, B. (2018). The Development of Smart House Model in Garut; The Advancement of Non-Formal Education $\begin{array}{lllll}\text { Program. Asian Journal of } & \text { Contemporary }\end{array}$ https://doi.org/10.18488/journal.137.2018.22.84.89

Tang, Y., \& Khan, M. B. U. (2018). Internal Law Enforcement Challenges in Bangladesh: An Analysis. Humanities and Social Sciences Letters, 6(3), 106-120. https://doi.org/10.18488/journal.73.2018.63.106.120

Telegram.org. "What can you do with Telegram?," 2016. [Online]. Available: https://Telegram.org/. [Accessed: 23-Jul-2016].

Wang, K., \& Yang, Z. (2018). The Research on Teaching of Mathematical Understanding in China. American Journal of Education and Learning, 3(2), 93-99. https://doi.org/10.20448/804.3.2.93.99

Zheng, J. (2018). The Incorporation of Subject Knowledge in Teaching Scientific Translation. International Journal of English Language and Literature Studies, 7(2), 45-49.

Zhu, W. J. Cao, Y. Xu, L. Yang, \& J. Kong. (2012). Fault-Tolerant RFID Reader Localization Based on Passive RFID Tags. 2183-2191. 